CHAPTER 12

\title{
Immaterial Labour and Reality TV: The Affective Surplus of Excess
}

\author{
Jacob Johanssen
}

\section{Introduction}

Drawing on discussions of neoliberalism, immaterial labour and exploitation of reality television participants, I argue in this chapter that those who appear on reality shows are exploited because they receive no monetary return for their performances. I use the British programme Embarrassing Bodies (Channel 4, 2007-2015) as an exemplary basis. I then seek to theorize the exploited labour on reality television through Debord's notion of the spectacle. I argue that in contemporary reality television the spectacle is amplified through affectivity and shaming. This is particularly evident in programmes that are about health and the body, such as Embarrassing Bodies. The spectacular labour depicted in such programmes may serve to attract audiences for entertainment purposes, as well as to discipline them so that they remain healthy and productive. Embarrassing Bodies is a medical reality show that features patients with common but also very rare medical conditions. The patients are seen by doctors, who also act as hosts of the show, and are then referred to specialists for subsequent treatment. The show is very graphic and patients undress in front of the camera to show their bodies. Operations are also partly broadcast. It is safe to

How to cite this book chapter:

Johanssen, J. 2017. Immaterial Labour and Reality TV: The Affective Surplus of Excess. In: Briziarelli, M. and Armano, E. (eds.). The Spectacle 2.0: Reading Debord in the Context of Digital Capitalism. Pp. 197-208. London: University of Westminster Press. DOI: https://doi.org/10.16997/book11.1. License: CC-BY-NC-ND 4.0 
say that the show knows no taboos in the showing of genitals, or other regions of the body more commonly signified as 'embarrassing'.

I end the chapter by turning to how Embarrassing Bodies is discussed on Twitter. Social media users often demonstrate an internalized, neoliberal ideology when they shame and dismiss patients. The spectacle is thus actively reproduced by audiences on social media.

\section{Neoliberalism, Reality Television and Labour}

Many scholars (Ouellette 2004; Palmer 2004; Andrejevic 2011; Wood and Skeggs 2011; Gilbert 2013) argue that reality television's emergence and continued proliferation may be seen in relation to neoliberalism and its development in the West. Reality television formats are a prime example of showcasing neoliberal values of self-responsibility, self-help and self-performance. Allison Hearn (2010) has linked reality television to Hardt and Negri's $(2000,2004)$ work on immaterial labour. She argues that the performance of reality television participants is one of individualism, affect and communication that is geared towards the production of an immaterial product: a television programme. What participants do on reality television shows are not only acts of performance but actual labour that contributes to profit harvested by production companies and television channels (Hearn 2010; Andrejevic 2011).

Reality television can likewise mean a relatively cheap way of production for television studios. Particularly the focus on ordinary people who are not professional actors guarantees less money is spent on salaries for the performers (Curnutt 2011). Deery (2014) has similarly argued that the multifaceted aspects of commercialization that surround reality television (cheap production costs, spin-off shows, product placements, websites etc.) have led to precarious conditions for participants:

Then, on-screen participants expect little or no pay and are generally underemployed aspiring actors or lower- and lower-middle-class employees whose casting could be considered a form of outsourcing to cheaper labor (Deery 2014, 20).

She concludes that the majority of reality show participants 'earn only a small per diem stipend that may not cover loss of wages or other expenses' (Deery 2014, 21). The same is true for the Embarrassing Bodies patients. Apart from the medical treatment and possibly a small fee, they receive no remuneration. The amount of profit that Channel 4 has made from the show is thus in no proportion to the money that is paid to the patients/workers. The question poses itself then, as Andrejevic (2011) notes, whether reality TV participants should be classified as workers or just participants. While such activities may not count as traditional wage-earning labour, they still contribute to the production of a 
commodity that generates exchange value. Andrejevic nonetheless argues that they are not exploited in the traditional sense of the wage labour model that Marx developed but in terms of affective and alienated labour that is more difficult to measure $(2011,27-29)$.

The aspect of exploitation of reality television participants has also been discussed by other scholars but is often only mentioned in passim (Brenton and Cohen 2003; Baltruschat 2009; West 2010; de Kloet and Landsberger 2012; Sender 2012). Baltruschat has called the working conditions of reality television contestants 'highly exploitative' $(2010,142)$. In their discussion of the Idols format, de Kloet and Landsberger stress that the performances of contestants should be seen for what it is. 'What is generally considered as fun, leisure and cultural activity very often constitutes free labour based on which different parties generate capital' (de Kloet and Landsberger 2012, 139). This notion of free labour (Terranova 2000) has also been discussed and conceptualized as 'immaterial labour' by the thinkers Antonio Negri, Michael Hardt $(2000,2004)$ and Mauricio Lazzarato (1996). Broadly speaking, the term designates new forms of labour that go beyond traditional factories and workplaces and stretch into all spheres of life and are not easily recognised as 'work'. It is the product of the labour process, which is itself material and physical, that is immaterial, such as a feeling of well-being, health or satisfaction (Hardt and Negri 2004, 108). To some extent, immaterial labour is about self-care, self-improvement and reinvention. However, there are some limits to the immaterial labour concept when applied to reality television participants, as Hearn (2010) maintains. While reality television performances are often about the very characteristics that the immaterial labour concept describes: individuality, affect, self-relationality, creativity, their end result is indeed measurable value creation for a television channel (Hearn 2010, 73). In the case of Embarrassing Bodies, the participants' labour on the show is indeed also about affect, individuality, wellbeing and embodiment but also its process (the sequences with the doctors, the operations, the 'after' shots) and yet it creates two things at once: a made-over body that is healthier thanks to medical treatments, as well as an immaterial television product that is broadcast on television and online.

Furthermore, I suggest that the participants are not only exploited in terms of monetary dimensions, they are exposed for entertainment value. They have to work by exposing themselves, talking of their shame and being commented on by the doctors (and audiences), in order to be granted their desired treatment and healing. I explore the specificities of that exploited labour further below by drawing on Debord's notion of the spectacle.

\section{Spectacular Labour}

Guy Debord argued that in the society of the spectacle, life itself has become reduced to a commodity. The spectacle reduces reality to an endless supply 
of commodifiable fragments, while encouraging us to focus on appearances. Our experience and way of living have been downgraded from 'having' to 'appearing'. Everything is about appearances. The society of the spectacle is, for Debord, a society of atomized and isolated individuals who are only united through a common exposure to the same images. The spectacle means that reality is replaced by images (Debord 2006). Contemporary reality television may be regarded as a logical continuum of such spectacle. Reality shows are devoid of any substance but are a mere showcase of form without essence. They stress the visual and emphasize processes of transformation that are exclusively tied to appearance and visibly observable behaviour. Viewers are made to believe that naughty children are turned into obedient and good children (Supernanny, Channel 4, 2004-2012), an aspiring entrepreneur is transformed into a successful businessperson (The Apprentice, BBC One, 2005-), young people are transformed into superstars (casting show formats), and so on and so forth. The individuals whose transformations we witness are of lesser importance than their displayed and observable mannerisms, bodily features, actions and styles.

The process from 'having' to 'appearing', that Debord writes of, is best exemplified through reality television. Any reality show promises both the contestants and the audience a spectacular transformation. Something artificially created for the sake of a particular format (e.g. different tasks that feature throughout an Apprentice season) ends in a new reality for the contestants. One is the winner and receives the investment, whereas the others have lost. This spectacle of appearance is further heightened in the many beauty reality shows where 'ugly' people are transformed into 'beautiful' ones.

Embarrassing Bodies occupies a particular and slightly different position in the spectacle of reality television. It is unparalleled in its graphicness and shameless visibility of bodies. Such an excessiveness of the spectacle is both achieved through the patients' labour/performance and how it is commented on by the doctors. While Debord argued that the spectacle comes to dominate society and reality, 'the spectacle, though it turns reality on its head, is itself a product of real activity' (Debord 2006, 14). While most reality shows are precisely about unreality, or as Debord might have called them 'society's real unreality' (13), Embarrassing Bodies and related shows that feature operations or visible bodily transformations, depict spectacular performances which are nonetheless rooted in reality that go beyond the spectacle's empty pretentiousness of reality. Whereas many reality shows are clearly not real but scripted, rehearsed and fake (Andrejevic 2004), medical reality shows feature real operations and observable outcomes. A wound is healed, excess fat is removed, a liver spot is cut out, and so on. We may therefore observe both an excessive and heightened spectacle that is achieved through the participants' labour of talking about their conditions, undressing, showing their bodies but, at the same time, a sense of reality becomes observable that escapes the spectacle's formulaic and sequential dramatization. This, as it were, surplus of the spectacle is particularly 
exemplified through the affective display of bodies. The bodies may be turned into spectacle but a quantum remains that escapes representation.

\section{Affect as Excess}

In the Comments, Debord specifically mentioned 'spectacular medicine and all the other similarly surprising examples of 'media excess" (Debord 1990, 6). The 'spectacle would be merely the excesses of the media' (7). We can continue and strengthen this line of thought via a focus on affect. Contemporary affect theories generally define affect as having abrupt, excessive, raw and intersubjective qualities. Affect suggests movement, messiness and excess. Bonner has argued that medical reality shows in particular 'produce an excess of affect' (Bonner 2005, 106). Similarly, Moseley (2000) has defined reality television as embodying 'the excessiveness of the ordinary' (Moseley 2000, 314) such as close ups of body parts that we all have. Misha Kavka has named reality shows a 'pornographic 'excess' of too much visibility' (Kavka 2009, 164). Its excessive affectivity is arguably the strongest feature of Embarrassing Bodies and many other reality shows. It attracts viewers through the very promise of a view into spectacular bodies few have seen before. I will now illustrate how bodies are portrayed. The camera often follows the participants into the operating theatre and shows parts of the surgical procedures in excruciating detail. In one sequence (S3, E9), the patient Claire is seen talking about her large labia that cause her discomfort.

Claire: $\quad$ Sometimes it'll be quite painful, erm, I'd have to kind of, put it out the way, otherwise it would pull and it would be sore.

Dr. Christian: It would get pushed inside and pull.

Claire: Yeah.

Dr. Christian: OK.

Claire: $\quad$ I have really bad dreams sometimes that I, I'm just so sick of it that I end up cutting it off, like it's really.

Dr. Christian: You're dreaming about cutting it off.

Claire: $\quad$ Yeah and that's just the thought of that scares me.

Dr. Christian: Well, the first thing is I really need to have a look. So, let's go over to the couch here. Come with me, all right, so if you just take those down for me.

[Claire pulls down her trousers and underwear.]

Claire: It's all kind of.

Dr. Christian: OK, do you tend to tuck them up inside or they go up inside? Claire: I try.

Dr. Christian: So, what we can see is that the right side is definitely much longer, isn't it? Than the left side and I can see that possibly that might rub on things, be causing the problems that you're getting. Pop your things back on and we'll have a chat (SE3, E9, 0.28-1.48). 
Later on in the episode, Claire's surgery is shown in close-up shots of the large labia.

For a second, Claire's face is seen and she appears to be unconscious. A long medical tube is inserted into her mouth that is wide open. The dominant colour is the green of the surgeon's clothing and gown that seems to separate Claire's genitalia from everything else. The female surgeon is seen tucking and pulling at the labia (that are zoomed in to an extreme close-up) with medical instruments. The surgeon stretches the excess tissue that fills the screen and skilfully makes cuts and insertions. She pulls at it and moves it until she finally cuts it off. The excess tissue is seen dangling from a pair of tweezers - suspended in a void until it is not visible to the viewer anymore. Blood is oozing out of the wound. It is being absorbed with a white cloth. The wound is being sutured.

In this sequence, the patient's body is rendered a spectacle through a focus on affectivity. What matters is not the subject as such but someone who is shown having a particular condition (i.e. large labia) that can be exploited for entertainment. At the same time, Claire receives the operation for free and one could argue that a symbolic exchange of gifts has taken place. She provides her body to the programme and receives the operation (Baudrillard 1981). However, she has also contributed exchange value to Channel 4 through her bodily condition being shown on the programme. In that sense, the labour does not only consist of the time and money needed by the patient to travel to the filming location, to spend hours on set waiting for her turn to be seen by a doctor, possibly shooting the above dialogue sequence multiple times and then having to wait until she can receive the surgery. Her labour is affective and immaterial and does not result in a tangible product that was produced. Rather, through her condition of having large labia, she has contributed to a particular episode that is broadcast on television and online. As part of the broadcast, Channel 4 is paid by advertisers for air time. Only in combination with the other workers/patients can one episode come together. They should therefore be paid a basic wage that should be calculated according to the overall hours that are spend in relation to the programme (including travel time, shooting, time spent in hospitals). There is thus a distinctive relation between economic aspects tied to exploitation of labour power and ideological aspects that emerge as a result of how that labour is turned into spectacle. While such labour may be difficult to measure and there is always a limit to its representation, as I suggested earlier, we can theorize it further through examining processes of shame and shaming.

\section{Shame and Sign Value}

From a psychoanalytic perspective, shame designates a failure to live up to one's own ideas of the self (Rizzuto 1991). This internalized failure is often caused by others, who have made us feel unable to live up to ideas of what the self should 
be. In one episode of Embarrassing Bodies, this failure is shown in Karen, who has suddenly developed a lot of acne:

I can't go to work, I can't go shopping. My husband's doing everything at the moment and I just look in the mirror all the time. It's just a nightmare. To me, it's taken Karen away. You know, how I was and, erm, I just don't feel that person anymore (S05, E08, 25.37-25.52).

The condition is represented here as having taken over the whole body. Karen cannot do anything anymore, her husband is doing everything. Her skin condition has 'taken Karen away'. She is seen equating herself with a nothing, an empty subject and her husband with 'everything. She cannot function anymore and her body has become unproductive for she cannot go shopping or go to work. Her body has lost value and agency. It is the acne that has taken ownership of her body and taken control in a spectacular sense. Her misery is turned into spectacle through being represented on Embarrassing Bodies. The above sequence may summarise reality television's obsession with the spectacle and with othering bodies. Karen is not only shown talking about her body, her narrative is interjected with many close-up shots of her face and acne. This unproductive body acquires use value for Channel 4 . Through the free labour of performance, it is turned into a spectacle that produces the Embarrassing Bodies commodity that is sold to advertisers in the form of air time. The useful body that is marked by shame and a bodily condition, has to produce itself on the show through labour such as speech acts that discuss the condition, undressing, showing of body parts, and so on in order to produce the television programme and, ultimately, to be offered treatment or advice. Karen is thus a worker whose performance contributes to the exchange value of Embarrassing Bodies. It is striking that she is seen speaking about herself in purely neoliberal terms. Her body has failed her and she is unable to work. This feeling of being unproductive is related to feelings of shame. Karen represents a subject who has been disciplined into conducting surveillance of her own body. Once any weaknesses are spotted, they need to be rooted out in order to stay healthy and productive. Two other examples may illustrate this further:

Narrator's voice: 5 years ago, thirty-year-old Trina underwent major surgery; though successful, it left a stomach turning legacy.

Trina: $\quad$ People stare quite a lot, I manage it, by wearing bigger clothes. It affects with my partner cos, er, I don't like him seeing me naked. [...]

Dr. Dawn: Trina, come on in, take a seat. How can I help you?

Trina: I'm here today to talk about my belly, erm, just from scaring, I've got deep scars.

Dr. Dawn: So, scarring, did you have an operation or an injury to your tummy? 
Trina:

Yeah, I had surgery done. I had part of my bowel removed, erm, from colitis.

Dr. Dawn: What where the symptoms that you were experiencing?

Trina:

Erm, just, erm, being able to control, erm, toilet, having accidents, daily, erm.

Dr. Dawn: Oh my word, so you were actually leaking faeces, were you?

Trina:

Basically.

Dr. Dawn: $\quad$ And was there a lot of blood and so on?

Trina:

Yeah (S5, E4: 08.32-10.26).

The above sequence further emphasizes the spectacular affectivity that I described in the previous section. It is not only shown through the body itself but also enacted through dialogue and speech acts by the doctors in particular. It can be seen adding to the patients' shame through focussing on the most embarrassing conditions of a person. Trina is seen saying that people stare at her and that she is further affected by her condition because she does not like to be naked in front of her partner. The gazes of others intensify her shame. Dr. Dawn reacts by asking questions that reinforce shame in Trina. Trina is apprehensive in her answer as the number of 'erms' indicate. She is seen responding by uttering words that do not form a complete sentence. Dr. Dawn replies with a performed shocking reaction: 'Oh my word, so you were actually leaking faeces, were you?' to which Trina merely utters a 'basically' Dr. Dawn's interrogation continues and she asks if there was 'a lot of blood and so on'. These graphic and highly intimate questions create powerful images in one's mind. Bodies are cast as 'embarrassing' while at the same time being invited on the programme because the show's narrative promises help and thus welcomes bodies back into 'normal' society. Bodies that are out of control are promised to be put in control again. We can see that, unlike most television programmes that deal with the body, Embarrassing Bodies is about assigning the body back to a healthy but more importantly, so-called normal state. It promises an end to the shameful body. The body is embraced by being allowed onto the programme, by being promised to be healed but also rejected through speech acts (and non-verbal communication) that ridicule or shame it. This focus on shame adds another dimension to the spectacle of reality television. The body is thus not only a worker's body that contributes to exchange value, as outlined, but also exemplifies Debord's discussion in The Society of the Spectacle of a shift from 'having' to 'appearing': 'all effective "having" must now derive both its immediate prestige and its ultimate raison dètre from appearances.' (Debord 2006, 16). We can see how in the case of reality television, this shift is not quite observable. Reality television designates a tension between exchange value that is generated through labour in the form of profit and sign value (see also Baudrillard 1981) that the workers embody and represent via their different conditions and appearances. In that sense, contra Debord and Baudrillard, the appearance is not more important than the use and exchange value. The 'embarrassing' body 
needs to have a spectacular appearance (deformed genitals, an observable skin condition, and so on) so that it can acquire a sign value and can be symbolically rendered 'embarrassing' but that appearance must also be true, rather than a mere spectacular semblance. The body on the medical reality show is not simply made to appear in a certain way but is shown as appearing. The appearing body has a real bodily condition. It is that combination of appearance and essence that makes it spectacular. Its sign value makes it accumulate exchange value for Channel 4 . The sign value of a particular condition is also underscored by use value for both the patient and the television channel when the patient receives advice and medical treatment. In that sense, something spectacular is transformed into something mundane, banal and 'normal'. Rather than being a spectacle without end, the spectacular body is transformed and afterwards no longer needed. Its sign and exchange values have diminished and a new, differently embarrassing body is needed for the show to continue. To that end, the programme presents a heightened relation between the economic and ideological aspects of contemporary neoliberalism. The patients are shown as embodying both an ideological surplus value and exchange value. They are only allowed on the show because they embody a unique medical condition that can be turned into spectacle. Ultimately, the spectacular body is discarded and abandoned by Channel 4 once it has been transformed into a 'normal' body through surgery or other medical procedures. This process of transformation, representative of any reality television narrative, results in medical treatments for patients but has also implications for audiences.

\section{Conclusion: Disciplining Bodies}

Debord $(1990,2006)$ argued that the spectacle does not only uphold capitalism's relations of production and guarantees continuing consumption, but it also maintains social order. In this chapter, I have related Debord's ideas to contemporary reality television by arguing that participants on reality shows conduct a form of labour that is exploited for profit maximization by television channels. The workers' bodies on Embarrassing Bodies acquire a particular use and sign value that contributes to the overall exchange value of the programme. This is amplified through the show's focus on affectivity and shame. However, affect, as many thinkers argue, is always situated at an intersection of representation, discourse and the non-representational (Kavka 2009). Something always escapes representation, particularly in the excessive visibility of the showing of surgical procedures on the programme. There is thus a limit to the representational ability of the spectacle. While the affectivity of the conditions is both heightened through the doctors' speech acts, it is also rendered into something discursive through naming and explaining of specific conditions. There is thus always an attempt on the part of the doctors to hold and bind the labour of the patients and make sure they are held accountable for their conditions and that they are 
healed (as shown in the dialogue extracts reproduced earlier). The body is disciplined and punished through speech acts that ridicule and bring out shame in order to be healed so that viewers are made aware of the symbolic and monetary costs an ill body brings to a (neoliberal) society. In neoliberalism a body has to function and work. There is no space for illness or other conditions, let alone embarrassment when it comes to the body. Bodies are normalized and brought back into the stream of productive bodies that make up society. The shock and awe factor of Embarrassing Bodies is thus used in order to pacify and discipline both patients and viewers. The patients are made healthy and productive again and through witnessing such a process, viewers are equally disciplined into staying healthy and productive. As a result, one could argue that the ideological goal behind the programme is to show a process that culminates in productive bodies that can get to work again. However, the programme may not only discipline patients and audiences but may also result in an ideological surplus for viewers that comes at the expense of the patients shown. Embarrassing Bodies is firmly situated within contemporary digital media. The show has a strong presence on Facebook and Twitter (Bennett and Medrado, 2013). While social media users may not be characteristic of the diversity of the show's television audience, exemplary tweets about the programme are nonetheless telling of how audiences make sense of it. A search for 'embarrassing bodies' on Twitter reveals a majority of Tweets that are dismissive of the programme and make fun of the patients. The show is frequently described as 'disgusting' and Twitter users articulate a disbelief about the subjects who expose their bodies. The show's ideological surplus for audiences, then, may be that they use it to (unconsciously) compensate for their own anxieties about their bodies. The society of the spectacle has morphed into a society of the Spectacle 2.0 whereby subjects are not only appeased and attracted by spectacles, but they proactively police their own and other's bodies through social media. The tweets may thus be seen as articulations of the internalized ideology propagated by Embarrassing Bodies. Patients are not only shamed on the programme, but also on social media where atomized and alienated individuals seek to strengthen their own subjectivities through devaluing others.

\section{References}

Andrejevic, Mark. 2004. Reality TV: The Work of Being Watched. Oxford: Rowman and Littlefield.

Andrejevic, Mark. 2011. 'Real-izing Exploitation'. In The Politics of Reality Television Global Perspectives, ed. Mirvan Kraidy, and Katherine Sender, 18-30. London: Routledge.

Baltruschat, Doris. 2009. 'Auditioning for Idol: The Audience Dimension of Format Franchising.' In TV Formats Worldwide. Localizing Global Programs, ed. Albert Moran, 129-146. Bristol: Intellect. 
Baudrillard, Jean. 1981. For a Critique of the Political Economy of the Sign. St. Louis: Telos Press.

Bennett, James, and Andrea Medrado. 2013. 'The Business of Multi-Platform Public Service: Online and at a Profit.' Media International Australia 146: 103-113.

Bonner, Frances. 2005. 'Looking Inside. Showing Medical Operations on Ordinary Television'. In The Spectacle of the Real. From Hollywood to Reality TV and Beyond, ed. Geoff King, 105-116. Chicago: University of Chicago Press.

Brenton, Sam and Reuben Cohen. 2003 Shooting People: Adventures in Reality $T V$. London: Verso.

Curnutt, Hugh. 2011. Durable Participants: A Generational Approach to Reality TV's 'Ordinary' Labor Pool. Media, Culture \& Society 33 (7): 1061-1076.

Debord, Guy. 1990. Comments on the Society of the Spectacle. London: Verso.

Debord, Guy. 2006. The Society of the Spectacle. Ninth Edition. New York: Zone Books.

Deery, June. 2014. 'Mapping Commercialization in Reality Television'. In A Companion to Reality Television, ed. Laurie Ouellette, 11-28. Chichester: Wiley and Blackwell.

de Kloet, Jeroen and Stefan Landsberger. 2012. 'Fandom, Politics and the Super Girl Contest in a Globalized China. In Adapting Idols. Authenticity, Identity and Performance in a Global Television Format, eds. Koos Zwaan and Jost de Bruin, 135-150. Farnham: Ashgate.

Gandolfi, Francois. (Director) (2010) Embarrassing Bodies. Season 3, Episode 9 [Television series episode]. London: Channel 4.

Gandolfi, Francois. (Director) (2012) Embarrassing Bodies. Season 5, Episode 4 [Television series episode]. London: Channel 4.

Gandolfi, Francois. (Director) (2012) Embarrassing Bodies. Season 5, Episode 8. [Television series episode]. London: Channel 4.

Gilbert, Jeremy. 2013. 'What Kind of Thing is "Neoliberalism"' New Formations: 80/81 (Neoliberal Culture)

Hardt, Michael and Antonio Negri. 2000. Empire. Cambridge, MA: Harvard University Press.

Hardt, Michael and Antonio Negri. 2004. Multitude: War and Democracy in the Age of Empire. New York: Penguin Books.

Hearn, Allison. 2010. Reality Television, The Hills and the Limits of the Immaterial Labour Thesis. tripleC: Communication, Capitalism \& Critique. Open Access Journal for a Global Sustainable Information Society 8 (1): 60-76.

Hill, Annette. 2005. Reality TV: Audiences and Popular Television. London: Routledge.

Kavka, Misha. 2009. Reality Television, Affect and Intimacy. Reality Matters. Basingstoke: Palgrave Macmillan.

Lazzarato, Mauricio. 1996. 'Immaterial Labour'. In Radical thought in Italy: A Potential Politics, eds. Paolo Virno and Antonio Negri, 133-150. Minneapolis and London: University of Minnesota Press. 
Marx, Karl. 1976. Capital: Volume 1. New York: Penguin.

McCarthy, Anna. 2007. Reality Television: A Neoliberal Theater of Suffering, Social Text, 25 (493): 17-42.

Moseley, Rachel. 2000. Makeover Takeover on British Television. Screen, 41, 3, 299-314.

Ouellette, Laurie. 2004. “Take Responsibility for Yourself': Judge Judy and the Neoliberal Citizen. In Reality TV: Remaking Television Culture, eds. Susan Murray and Laurie Ouellette, 243-259. New York: New York University Press.

Palmer, Gareth. 2004. 'The New You: Class and Transformation in Lifestyle Television. In Understanding Reality Television, eds. Su Holmes and Deborah Jermyn, 173-190. London: Routledge.

Rizzuto, Ana-Maria. 1991. Shame in Psychoanalysis: The Function of Unconscious Fantasies. International Journal of Psycho-Analysis, 72: 297-312.

Sender, Katherine. 2012. The Makeover: Reality Television and Reflexive Audiences. New York: New York University Press.

Terranova, Tiziana. 2000. Free Labor: Producing Culture for the Digital Economy. Social Text 18 (2): 33-58.

West, Emily 2010. 'Reality Nations: An International Comparison of the Historical Reality Genre'. In Reality Television - Merging the Global and the Local, ed. Armin Hetsroni, 259-282. New York: Nova Science Publishers. Wood, Helen and Skeggs, Bev. 2011. Reality Television and Class. Palgrave. 